\title{
ESTIMATION OF HETROSIS, GENERAL AND SPECIFIC COMBINING ABILITY USING DIALLEL CROSS IN MAIZE (Zea mays L.)
}

\author{
A. Abas Mohamad \\ A. N. Mohamad Amin \\ S. Ismaeel Towfiq \\ Field Crop Sci. Dept., College of Agriculture, Sulaimania Univ., Iraq
}

\begin{abstract}
Five maize genotypes (CMT 033066, CMT 033060, CMTQ 033072, CMS 983046, CMTQ 033070) were used in 5x5 diallel crossing with out reciprocals. Combining ability for some quantitative and physiological traits was studied. F1 hybrids and the parental genotypes were grown in a Randomized Complete Block Design with three replications. The analysis of data carried out according to Griffing (1956) Method 2 (fixed model). Significant mean squares due to genotypes were exhibited for all traits. Highly significant mean squares due to GCA was exhibited for all traits, except Photosynthetic rate which was found non significant. Also highly significant mean squares due to SCA was obtained for all traits except, photosynthetic rate, transpiration rate which was significant only and stomatal conductance was found not significant. The ratio $\sigma^{2} \mathrm{GCA} / \sigma^{2} \mathrm{SCA}$ was less than one for all traits, indicating the importance of non additive gene effect, with the exception of plant height which was more than one, indicating the importance of additive gene effect, and the average degree of dominance values was more than one for all traits, except plant high, indicating the over dominance gene effect role in controlling these characters. Heritability in broad sense was high for all studied characters, while in narrow sense heritability was high for plant height only, moderate for transpiration rate and stomatal conductance and low for the remainder traits.
\end{abstract}

\section{INTRODUCTION}

Maize (Zea mays L.) is one of the most important cereals both for human and animal consumption. Successful cultivation markedly depend on the right choice of varieties .Variety selection trails to identify the best suitable varieties for given areas frequently necessary. In recent years, major research activities have been directed on the physiological basis of maize growth and productivity (Koscielniak et al., 2005 and Malti et al., 2006).

Physiological bases for the hybrids selection achieved by measurements of net photosynthetic and transpiration rates, stomatal conductance, and intercellular $\mathrm{CO}_{2}$ concentration. Measuring of those factors has great importance of maize parental inbred lines able to produce $\mathrm{F} 1$ hybrids with a high $\mathrm{CO}_{2}$ assimilation rate during growth (Koscielniak et al., 2005).

Diallel crossing programs have been applied to provide a systematic approach for the detection of suitable parents and crosses for investigated characters. In addition, diallel analysis gives plant breeders the opportunity to choose the efficient selection method by allowing them to estimate several genetic parameters (Unay et al., 2004). Combining ability describes the breeding values of parental lines to produce hybrids. 
This study was conducted by the senior author as apart of his ph.D.

Received 29/10/2006 accepted 23/5/2007

In many studies, GCA effects for parents and SCA effects for crosses were estimated in maize (Araujo and Miranda 2001). Non-additive gene effects for grain yield were found to be significant in maize (Dehanghpour et al., 1996 and Kalla et al., 2001) which suggested that several combination among parental lines by their mean performance and genetic nature had the potential for the development of more yielding and earlier genotypes .

Heterosis is defined as the deviation of F1 over the parental mean. There are averages of $55 \%$ midparent heterosis for variety crosses and $105 \%$ or better parent heterosis for inbred crosses in maize (Larish and Brwbaker, 1999 and Muhammad and Muhammad, 2002) .

The aim of present study was to estimate the heterosis, GCA, SCA effects and some genetic parameters for growth and some physiological characters in a 5 X5 half diallel maize crossing system.

\section{MATERIALS AND METHODS}

Five genotypes of maize (Zea mays L.) from CYMMIT organization (CMT033066, CMT033060, CMTQ033072, CMS983046, CMTQ033070) were selected based on preliminary field observations of their growth performance and physiological bases especially photosynthetic and transpiration rates.

In Autumn 2005, selected genotypes were seeded at Kanipanka

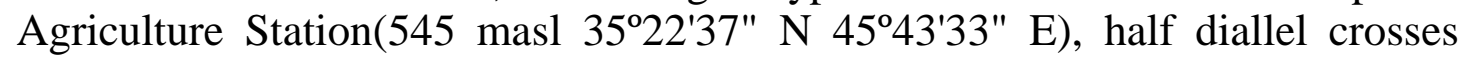
were conducted among them, each hybridization done in three cobs as well as self pollination to male parents, obtaining 10 hybrids. In the next season Spring 2006 parents and their F1s were identified in comparative investigation, using RCBD design with three replication. At maturity 5 plants from each genotype were taken randomly for recording observation. The data were taken from individual plants and arranged for each plot for: Plant height, LAI, No.of leaves, Total dry biomass weight (gm), dry weight of leaves, \%Leaf/Stem ratio, Photosynthetic rate $\mu$ Mole $\mathrm{m}^{2} \mathrm{~s}^{-1}$, transpiration rate. mMole $\mathrm{m}^{-1} \mathrm{~s}^{-1}$, Stomatal Conductance Mole $\mathrm{m}^{2} \mathrm{~s}^{-1}$.

At tasseling while the plant leaves have completed their maximum size, all physiological parameters were measured by using LCA4 instrument which is an infrared gas analyzer.

Data analyzed according to method 2 of Griffing (1956) (fixed model), and the following estimaters were carried out as out lined previosly (Singh and chaudhary 1985):

1.Heterosis as percentage of $\mathrm{F} 1$ deviation from the mid parents .

2.General combining ability effects for parents and specific combining ability effects for crosses.

3. The variance of general and specific combining ability effects for each parents.

4. Estimation of some genetic parameters:

Additive, dominance, environmental variances, heritability (in broad and narrow sense) and average degree of dominance. 


\section{RESUTES AND DISCUSSION}

Table (1) shows a significant differences among genotypes in all the traits, total variation among the genotypes was partitioned in to the variation due to general \& specific combining ability .It was shown that mean square due to GCA were highly significant for all traits except for the number of leaves/ plant; and photosynthetic rate which were found to be not significant. The mean squares due to SCA were found to be highly significant for all traits except the transpiration rate which was significant and stomatal conductance non significant. It was indicated from table 2 that parent 1 gave a highest plant height $(241.00) \mathrm{cm}$, while parent 5 exhibited a maximum values for No . of leaves/plant ; LAI; Leaves dry weight and leaf /stem ratio with values 18.33; $7.40 ; 154.21 \mathrm{gm}$ and 0.53 respectively. Parent 4 gave the highest values for total biomass; Photosynthetic rate; Transpiration rate and Stomatal conductance with the value $342.42 \mathrm{gm} 31.99 ; 7.21$ and 0.23 respectively. Some physiological traits were studied by (Koscielniak et al., 2005)and shown similar results to the present study.

The differences between parents reflected obviously on their hybrids means, the maximum biomass value $392.38 \mathrm{gm} \&$ Photosynthetic rate $25.70 \mu \mathrm{Molm}^{2} \mathrm{~s}^{-1}$ was shown by the hybrid $1 \times 3$, while the hybrid $1 \mathrm{x} 4$ gave the highest value of number of leaves /plant 19.33; LAI 7.57 and leaf/ stem ratio 0.50 . Hybrid $2 \times 3$ showed the greatest value of plant height $287.33 \mathrm{~cm}$ and leaves dry weight $144.61 \mathrm{gm}$, and the hybrid $4 \times 5$ gave the maximum value of transpiration rate $5.8 \&$ stomatal Conductance 0.15 .

Differences between parents \& their hybrids caused a significant positive $\&$ negative heterosis of hybrids as compared to mid - parental values in all traits (Table 3) similar results were reported by El-Baroudiy (1999) and Mohammad (2005).

Hybrid $1 \times 4$ exhibited the highest positive heterosis for LAI $23.39 \%$ \& leaf/stem ratio $42.85 \%$, while the hybrid $2 \times 3$ gave the maximum positive heterosis for plant height $25.47 \%$; No of leaves /plant 14.01;leaves dry weight / plant $60.26 \%$ \& total biomass/plant $64.86 \%$. Maximum positive heterosis for Tr. Rate $22.71 \%$ \& stomatal conductance $40.00 \%$ were exhibited by the hybrid $2 \times 5$, while for Photosynthetic rate $24.57 \%$ had shown by the hybrid 3x4, similar resultes obtained by El-Baroudiy (1999) and Mohammad (2005).

The effect of over-dominance genes for parent with a higher value is responsible for the positive heterosis but the heterosis with a negative values caused by the effect of partial dominance genes for parent with lower value(Towfiq, 2004),

The estimates of general combining ability effects of parents and their corresponding standard errors are presented in table (4).Parent 2 showed the highest significant positive values of GCA effect for plant height, LAI, leaf/stem ratio and stomatal conductance, and parent 5 showed significant positive values of GCA effect for plant height, LAI, total biomass and leaf /stem ratio, these two parents were shown a significant negative values for the other characters. 
The high positive value of GCA effect of them indicate that their contribution in transferring these characters to their hybrids is high, similar results were reported by El-Baroudiy (1999), Unay et al. (2004), Rezaei and Roohi (2004), Towfiq (2004) and Mohammad (2005).

Estimates of specific combining ability effects of hybrids were exhibited in Table (5). The hybrid 2x3gave a significant positive values of SCA effect of most of characters (plant height, no. of leaves/plant, LAI, leaves dry weight, total biomass and photosynthetic rate with the values of $(28.033,1.666,0.275$, $37.666,82.127,1.956)$, respectively and hybrid $1 \times 2$ gave significant positive value of SCA for plant height . No. of leaves/plant, LAI, leaves dry weight and leaf/stem ratio, with the value of $(39.119,0.808,0.716,26.843,0.105)$, respectively. 
Table (1) : Combining ability analysis for studied traits in a 5x5 diallel cross in maize

\begin{tabular}{|c|c|c|c|c|c|}
\hline \multirow{2}{*}{ Source of Variation } & \multicolumn{5}{|c|}{ Mean of Squares } \\
\hline & Replications & Genotypes & GCA & SCA & $\sigma 2 \mathrm{e}$ \\
\hline $\begin{array}{ll}\text { Character } & \mathrm{df} \\
\end{array}$ & 2 & 14 & 4 & 10 & 28 \\
\hline Plant Height & 137.756 & $1406.279 * *$ & $4113.747 * *$ & $323.919 * *$ & 11.112 \\
\hline Number of leaves/plant & 0.600 & $2.724 * *$ & 1.037 N.S & $3.371 * *$ & 0.552 \\
\hline LAI & 0.089 & $1.242 * *$ & $1.385 * *$ & $1.185 * *$ & 0.062 \\
\hline Leaves dry Weight & 18.767 & $1958.731 * *$ & $1276.599 * *$ & $2231.583 * *$ & 27.279 \\
\hline Total Biomass & 1.689 & $13032.860 * *$ & $6711.992 * *$ & $15561.213 * *$ & 102.395 \\
\hline Leaf/Stem ratio & 0.0006 & $0.0179 * *$ & $0.0047 * *$ & $0.0233 * *$ & 0.0006 \\
\hline Photosynthetic rate $\mu$ molm$^{2} \mathrm{~s}-1$ & 18.574 & $39.335 *$ & 23.189 N.S & $45.793 * *$ & 18.142 \\
\hline Transpiration rate mmolm ${ }^{2} \mathrm{~s}-1$ & 0.605 & $2.305 *$ & $4.454 * *$ & $1.445 *$ & 0.583 \\
\hline $\begin{array}{l}\text { Stomatal conductance molm² } \\
\text { s- }\end{array}$ & 0.00033 & $0.0058 * *$ & $0.0131 * *$ & 0.0029 N.S & 0.00144 \\
\hline
\end{tabular}


Table (2) : F1 Hybrids and their parents means for studied characters.

\begin{tabular}{|c|c|c|c|c|c|c|c|c|c|}
\hline $\begin{array}{c}\text { genotype } \\
\mathrm{s}\end{array}$ & $\begin{array}{c}\text { Plant height } \\
\mathrm{cm}\end{array}$ & $\begin{array}{c}\text { No. of } \\
\text { leaves/ } \\
\text { plant }\end{array}$ & LAI & $\begin{array}{c}\text { Leaves dry } \\
\text { weight } \\
\text { gm/plant }\end{array}$ & $\begin{array}{c}\text { Total } \\
\text { biomass } \\
\text { gm/plan } \\
\mathrm{t}\end{array}$ & $\begin{array}{c}\text { Leaf/ste } \\
\mathrm{m}\end{array}$ & $\begin{array}{c}\text { Photosynt } \\
\text { hetic rate } \\
\mu \text { molm }^{2} \mathrm{~s}- \\
1\end{array}$ & $\begin{array}{c}\text { Transpira } \\
\text { tion rat } \\
\mathrm{mmolm}^{2} \mathrm{~s} \\
-1\end{array}$ & $\begin{array}{c}\text { Stomatal } \\
\text { conductanc } \\
\mathrm{e} \\
\mathrm{molm}^{2} \mathrm{~s}^{-1}\end{array}$ \\
\hline $1 * 2$ & 267.00 & 18.33 & 7.53 & 131.96 & 258.00 & 0.51 & 22.89 & 5.61 & 0.14 \\
\hline $1 * 3$ & 266.33 & 17.00 & 5.63 & 125.55 & 392.38 & 0.32 & 25.70 & 4.13 & 0.10 \\
\hline $1 * 4$ & 252.67 & 19.33 & 7.57 & 104.82 & 192.01 & 0.50 & 20.44 & 5.01 & 0.12 \\
\hline $1 * 5$ & 283.67 & 16.67 & 6.83 & 72.46 & 221.58 & 0.30 & 20.54 & 4.18 & 0.11 \\
\hline $2 * 3$ & 287.33 & 19.00 & 7.07 & 144.61 & 361.36 & 0.40 & 23.71 & 5.37 & 0.12 \\
\hline $2 * 4$ & 249.33 & 17.00 & 6.20 & 65.38 & 171.04 & 0.38 & 22.76 & 4.82 & 0.14 \\
\hline $2 * 5$ & 246.67 & 17.00 & 6.87 & 101.94 & 266.85 & 0.38 & 23.15 & 6.51 & 0.21 \\
\hline $3 * 4$ & 226.67 & 17.00 & 6.73 & 92.08 & 309.38 & 0.30 & 19.86 & 4.92 & 0.12 \\
\hline $3 * 5$ & 262.3 & 18.33 & 7.40 & 121.29 & 345.87 & 0.35 & 20.99 & 4.66 & 0.07 \\
\hline $4 * 5$ & 230.33 & 18.00 & 7.63 & 94.32 & 263.32 & 0.36 & 15.57 & 5.80 & 0.15 \\
\hline 1 & 241.00 & 18.00 & 6.00 & 119.70 & 313.06 & 0.38 & 21.21 & 5.00 & 0.12 \\
\hline 2 & 235.33 & 16.00 & 7.37 & 78.71 & 220.65 & 0.36 & 18.96 & 5.90 & 0.18 \\
\hline 3 & 222.67 & 17.33 & 6.30 & 101.75 & 217.72 & 0.47 & 20.67 & 4.24 & 0.08 \\
\hline 4 & 235.67 & 16.67 & 6.27 & 110.40 & 342.42 & 0.32 & 31.99 & 7.21 & 0.23 \\
\hline 5 & 215.67 & 18.33 & 7.40 & 154.21 & 289.84 & 0.53 & 20.84 & 4.71 & 0.12 \\
\hline LSD & 5.574 & 1.243 & 0.418 & 8.733 & 16.921 & 0.040 & 7.122 & 1.277 & 0.063 \\
\hline 0.05 & & & & & & & & & \\
\hline G.M. & 248.178 & 17.60 & 6.853 & 107.943 & 277.699 & 0.391 & 21.952 & 5.204 & 0.135 \\
\hline
\end{tabular}


Table (3) : Heterosis as a percentage of F1 deviation from the mid parental value for studied characters.

\begin{tabular}{|c|c|c|c|c|c|c|c|c|c|}
\hline $\begin{array}{c}\text { Hybrid } \\
\mathrm{s}\end{array}$ & $\begin{array}{c}\text { Plant } \\
\text { heigh } \\
\mathrm{t} \mathrm{cm}\end{array}$ & $\begin{array}{c}\text { No. of } \\
\text { leaves/plan } \\
\mathrm{t}\end{array}$ & LAI & $\begin{array}{c}\text { Leaves } \\
\text { dry } \\
\text { Wt./plan } \\
\mathrm{tgm}\end{array}$ & $\begin{array}{c}\text { Total } \\
\text { biomass } \\
\mathrm{cm} / \text { plant }\end{array}$ & $\begin{array}{c}\text { Leaf/ste } \\
\mathrm{m}\end{array}$ & $\begin{array}{c}\text { Photosynthet } \\
\text { ic rate } \\
\mu \text { molm }^{2} \mathrm{~s}^{-1}\end{array}$ & $\begin{array}{c}\text { Transpiratio } \\
\mathrm{n} \\
\text { Rate } \\
\mathrm{mmolm}^{2} \mathrm{~s}^{-1}\end{array}$ & $\begin{array}{c}\text { Stomatal } \\
\text { conductanc } \\
\mathrm{e} \\
\mathrm{molm}^{2} \mathrm{~s}^{-1}\end{array}$ \\
\hline $2 * 3$ & 25.47 & 14.01 & 3.44 & 60.26 & 64.86 & -3.61 & 19.65 & 5.91 & -7.69 \\
\hline $1 * 2$ & 12.11 & 7.82 & 12.64 & 33.01 & -3.32 & 37.83 & 13.96 & 2.93 & -6.66 \\
\hline $1 * 3$ & 14.88 & -3.76 & -8.45 & 13.38 & 47.85 & -24.70 & 22.75 & -10.60 & 0.00 \\
\hline S.E & 2.837 & 2.146 & 3.307 & 10.094 & 11.573 & 8.749 & 6.002 & 4.539 & 7.529 \\
\hline $3 * 5$ & 19.69 & 2.80 & 8.03 & -5.22 & 36.28 & -30.00 & 1.13 & 3.91 & -30.00 \\
\hline $1 * 4$ & 6.01 & 11.50 & 23.39 & -8.89 & -41.41 & 42.85 & -23.15 & -17.93 & -31.42 \\
\hline $2 * 5$ & 9.39 & -0.96 & -6.97 & -12.46 & 4.54 & -16.48 & 16.33 & 22.71 & 40.0 \\
\hline $3 * 4$ & -1.09 & 0.00 & 7.08 & -13.19 & 10.46 & -24.05 & 24.57 & -14.06 & -22.58 \\
\hline $4 * 5$ & 2.06 & 2.85 & 11.63 & -28.71 & -16.70 & -16.64 & -41.05 & -2.68 & -14.28 \\
\hline $2 * 4$ & 5.87 & 4.07 & -9.09 & -30.85 & -39.24 & 11.76 & -10.65 & -26.46 & -31.70 \\
\hline $1 * 5$ & 23.22 & -8.23 & 1.94 & -47.09 & -26.49 & -34.06 & -2.30 & -13.90 & -8.33 \\
\hline
\end{tabular}

Table (4) : Estimates of general combining ability effects of the parents for studied characters.

\begin{tabular}{|c|c|c|c|c|c|c|c|c|c|}
\hline Parents & $\begin{array}{c}\text { Plant } \\
\text { height } \\
\mathrm{cm}\end{array}$ & $\begin{array}{c}\text { No. of } \\
\text { leaves/plant }\end{array}$ & LAI & $\begin{array}{c}\text { Leaves } \\
\text { Dry Wt. } \\
\mathrm{gm}\end{array}$ & $\begin{array}{c}\text { Total } \\
\text { biomass } \\
\mathrm{Gm}\end{array}$ & $\begin{array}{c}\text { Leaf/stem } \\
\begin{array}{c}\text { Photosynthetic } \\
\text { rate } \\
\mu \mathrm{molm}^{2} \mathrm{~s}^{-1}\end{array}\end{array}$ & $\begin{array}{c}\text { Transpiration } \\
\text { rate } \\
\mathrm{mmolm}^{2} \mathrm{~s}^{1}\end{array}$ & $\begin{array}{c}\text { Stomatal } \\
\text { conductance } \\
\mathrm{molm}^{2} \mathrm{~s}-{ }^{1}\end{array}$ \\
\hline 1 & -23.467 & 0.248 & -0.222 & 3.789 & 3.413 & 0.0068 & 0.041 & -0.329 & -0.013 \\
\hline 2 & 12.628 & -0.322 & 0.183 & -6.621 & -23.949 & 0.0069 & -0.182 & 0.412 & 0.023 \\
\hline 3 & 7.962 & 0.057 & -0.241 & 5.621 & 25.462 & -0.0061 & -0.015 & -0.523 & -0.033 \\
\hline 4 & -0.276 & -0.133 & -0.065 & -10.039 & -6.515 & -0.0229 & 1.556 & 0.535 & 0.026 \\
\hline 5 & 3.152 & 0.152 & 0.345 & 7.250 & 1.589 & 0.0153 & -1.400 & -0.095 & -0.003 \\
\hline S.E & 1.029 & 0.397 & 0.134 & 1.612 & 3.122 & 0.0074 & 1.314 & 0.235 & 0.012 \\
\hline
\end{tabular}


The positive effect values of SCA in these two hybrids resulted in gene combinations of different degree of $\sigma^{2} \mathrm{~g}^{\wedge} \mathrm{ii}$, which means the validity of the parents to improve these characters and indicate the usability of these parents in the future breeding program (Mohammad, 2005) .

The parents with high value of $\sigma^{2} \mathrm{~g}^{\wedge} \mathrm{ii}$ indicate their tendency to contribute the inheritance of this character to their hybrids. The estimation of the variance of specific combining ability effect $\sigma^{2} \mathrm{si}^{\wedge} \mathrm{j}$ of parents for traits studied presented in table (7) Parent 1 gave the highest value of this variance in most of the traits studied ,such as plant height (9067.0), No. of leaves/plant (5.586), LAI (2.089), leaves dry weight, (2948.9), total biomass(17869.9) and leaf/stem ratio $(0.044)$ but parent 2 gave the maximum variance of $\sigma^{2} \mathrm{si}^{\wedge} \mathrm{j}$ for transpiration rate (3.327) and stomatal conductance (0.00437).

Parents with high values of $\sigma^{2} \mathrm{si}^{\wedge} \mathrm{j}$ indicate the ability of these parents to participate in the inheritance of this character to one or a few number of their hybrids, like hybrids $1 \times 2$ and $2 \times 3$ but the lowest value of this variance means the ability of these parents to participate in inheritance of the character to a large number of their hybrids.

Table (8) describes some genetic parameters for studied traits .The variance due to SCA was greater than the variance due to GCA in all traits except plant height, \& the ratio of $\sigma^{2}$ gca $/ \sigma^{2}$ sca was less than one in all traits except plant height, similar observations noticed in some previous studies (Singh and Chaudhary,1985, Muhammad and Muhammad, 2002, Rezaei and Roohi, 2004, Towfiq, 2004, Mohammad, 2005 and Tollenaar, 2006).

These results confirm a large contribution of non - additive gene action in the inheritance of all characters except of plant height. The average degree of dominance were found to be more than one in all traits except plant height .The present study confirm that these traits under the over- dominance gene action \& the predominance of non - additive gene actions in the inheritance of these traits.

Heritability in broad sense were high for all traits \& ranged between 0.711 for photosynthetic rate to 0.994 for total biomass, but in narrow sense was high for plant height 0.783 , considering that selection in early generation for this trait should be effective, while in most of the characters the value of heritability in narrow sense was low, confirming the usability of hybridization method in the improvement of these traits (Towfiq, 2004).

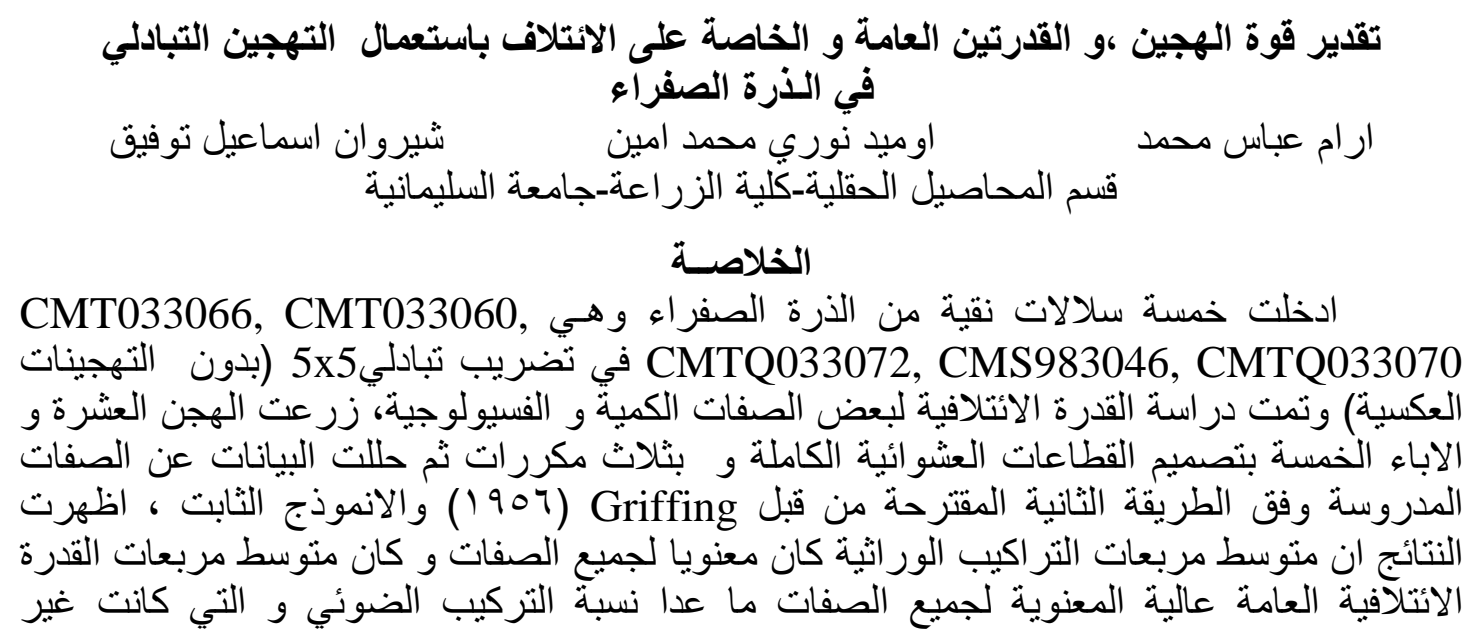




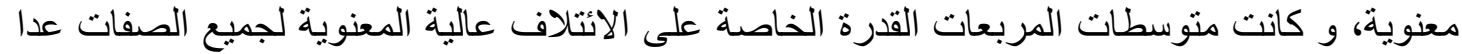

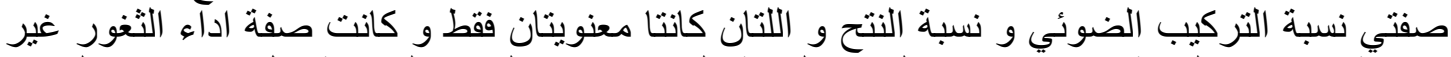

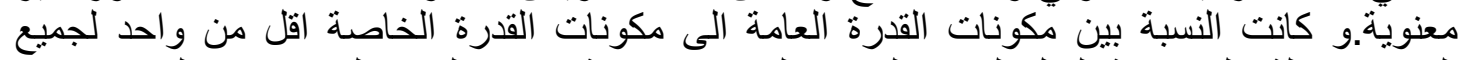

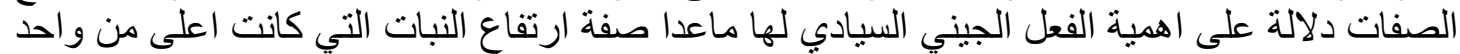

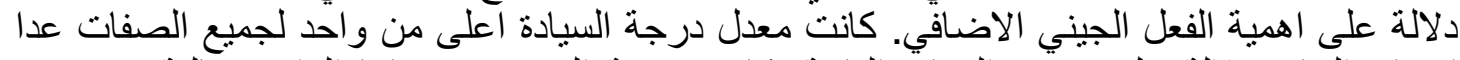

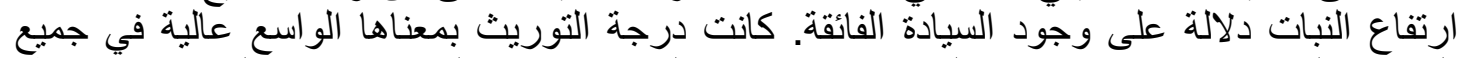

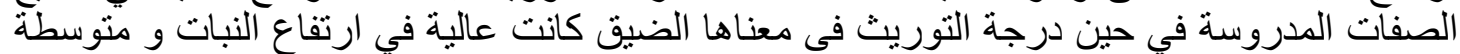
REFERENCES

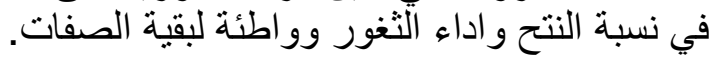

Araujo.P. M.and J.B. Miranda(2001).Analysis of diallel cross for evaluation of maize populations across environments . Crop Breeding and Appl.Biotech.1:255-262.

Dehanghpour,Z.,B.Edaie and M.Moghaddam(1996).Diallel analysis of agronomic characters in white endosperm maize .J.Genet and Breeding $.50: 357-365$.

El-Baroudiy,Mohamed Mohamed Mossad(1999).Partial Diallel Cross Analysis for Maize (Zea maize L.) Inbred Lines. A Thesis submitted to the College of Agriculture ,University of Baghdad for the degree of Doctor of Philosophy.(in Arabic).

Kalla,V.,R. Kumar and A.K.Basandral(2001).Combining ability analysis and gene action estimates of yield and yield contributing characters in maize.Crop Res.Hisar.22:102-106.

Koscielniak.J,F.Janowiak, and Z.Kurczych (2005).Increase in photosynthesis of maize hybrids (Zea mays L.)at suboptimal temperature $\left(15^{\circ} \mathrm{C}\right)$ by selection of parental lines on the basis of chlorophyll a fluorescence measurements. Photosenthetica 43(1):125-143

Larish L.,L.B.and J.L.Brwbaker(1999).Diallel analysis of temperate and tropical popmaizes .Maydica .44:279-284.

Malti.K.R, P.Vidyasagar and V.P.Singh (2006)(Research trends on physiological basis of crop growth and productivity in maize (Zea mays L.) $-\mathrm{A}$ review) Res .on crops 7(1):13-43 ,Vibha Adrotech Ltd.501,Subhan Sirisampada ,rajbhavan Road Samajiguda,Hyderabad500 082,(A..P.),India

Mohammad,Shahla Mahmood(2005).Full Diallel Crosses and Estimation of several Genetic Parametars of Maize.A Thesis submitted to the College of Agriculture ,University of Salahadden-Erbil for the degree of Doctor of Philosophy.(in Arabic).

Muhammad,Y.and S.Muhammad (2002).Estimates of heritability for some quantitative characters in maize .Int.J.Agric.and Biology.4:103-104.

Rezaei.A.H. and V.Roohi(2004).Estimates genetic parameters in corn(Zea maysL)based on daillel crossing. Faculty of Agriculture ,Shahrekord University .Shahreko.

Singh,R.K.and B.D. Chuadhary(1985).Biometrical method in quantititative genetic Analysis.Rev.ed,pp.ed,pp318,Kalyani publishers, Ludhiana,New Delhi.India

Towfiq,Sherwan Ismaeel(2004).Partial Diallel Crossing in Common and Durum Wheat .A Dissertation Submitted to the College of Agriculture ,University of Sulaimani for the degree of Doctor of Philosophy.

Tollenaar,Thijs(2006).Maize:A case history. Department of plant Agriculrure ,University of Gulph. 
Unay.A., Huseyin Basal, Cahit Konak(2004). Inheritance of grain Yield in a half-Diallel Maize Population. Adnan Menders University, Agricultural Faculty, Field Crops Dept., Aydin-TURKEY 
Table (5) : Estimates of specific combining ability effects for studied characters.

\begin{tabular}{|c|c|c|c|c|c|c|c|c|c|}
\hline Hybrids & $\begin{array}{c}\text { Plant } \\
\text { height } \\
\mathrm{cm}\end{array}$ & $\begin{array}{c}\text { No. of } \\
\text { leaves/plant }\end{array}$ & LAI & $\begin{array}{c}\text { Leaves } \\
\text { Dry Wt. } \\
\mathrm{gm}\end{array}$ & $\begin{array}{c}\text { Total } \\
\text { biomass } \\
\mathrm{gm}\end{array}$ & Leaf/stem & $\begin{array}{c}\text { Photosynthetic } \\
\text { rate } \mu \mathrm{molm}^{2} \mathrm{~s}^{-1}\end{array}$ & $\begin{array}{c}\text { Transpiration } \\
\text { rate } \\
\mathrm{mmolm}^{2} \mathrm{~s}^{-1}\end{array}$ & $\begin{array}{c}\text { Stomatal } \\
\text { conductance } \\
\mathrm{molm}^{2} \mathrm{~s}{ }^{1}\end{array}$ \\
\hline $1 * 2$ & 39.119 & 0.808 & 0.716 & 26.843 & 0.837 & 0.105 & 1.079 & 0.323 & -0.005 \\
\hline $1 * 3$ & 43.129 & -0.905 & -0.761 & 8.197 & 85.804 & -0.072 & 3.722 & -0.221 & 0.011 \\
\hline $1 * 4$ & 37.701 & 1.615 & 1.003 & 3.126 & -82.586 & 0.125 & -3.109 & -0.400 & -0.028 \\
\hline $1 * 5$ & 65.273 & -1.330 & -0.146 & -46.523 & -61.116 & -0.113 & -0.053 & -0.599 & -0.009 \\
\hline $2 * 3$ & 28.033 & 1.666 & 0.275 & 37.666 & 82.157 & 0.008 & 1.956 & 0.277 & -0.005 \\
\hline $2 * 4$ & -1.428 & -0.143 & -0.771 & -25.902 & 067.192 & 0.005 & -0.566 & -1.332 & -0.044 \\
\hline $2 * 5$ & -7.823 & -0.429 & -0.511 & -6.631 & 8.515 & -0.033 & 2.781 & 0.989 & 0.056 \\
\hline $3 * 4$ & -18.728 & -0.524 & 0.182 & -11.446 & 12.734 & -0.062 & -3.633 & -0.296 & -0.008 \\
\hline $3 * 5$ & -12.510 & 0.520 & 0.443 & 0.475 & 14.121 & -0.050 & 0.453 & 0.064 & -0.029 \\
\hline $4 * 5$ & -11.252 & 0.381 & 0.497 & -10.835 & -9.452 & -0.023 & -6.539 & 0.155 & -0.008 \\
\hline S.E & 2.519 & 0.562 & 0.189 & 3.948 & 7.649 & 0.018 & 3.219 & 0.577 & 0.029 \\
\hline
\end{tabular}

Table (6) : Estimates of the variance of general combining ability effect of the parents for studied characters.

\begin{tabular}{|c|c|c|c|c|c|c|c|c|c|}
\hline Parents & $\begin{array}{c}\text { Plant } \\
\text { height }\end{array}$ & $\begin{array}{c}\text { No. of } \\
\text { leaves/plant }\end{array}$ & LAI & $\begin{array}{c}\text { Leaves } \\
\text { Dry Wt. } \\
\text { gm }\end{array}$ & $\begin{array}{c}\text { Total } \\
\text { biomass } \\
\text { gm }\end{array}$ & $\begin{array}{c}\text { Leaf/stem } \\
\begin{array}{c}\text { Photosynthetic } \\
\text { rate } \\
\mu \mathrm{molm}^{2} \mathrm{~s}-\end{array}\end{array}$ & $\begin{array}{c}\text { Transpiration } \\
\text { rate } \\
\mathrm{mmolm}^{2} \mathrm{~s}-\end{array}$ & $\begin{array}{c}\text { Stomatal } \\
\text { conductance } \\
\mathrm{molm}^{2} \mathrm{~s}-1\end{array}$ \\
\hline 1 & 549.429 & -1.849 & 0.0421 & 11.238 & -0.058 & -0.000022 & -2.071 & 0.042 & -0.000001 \\
\hline 2 & 158.195 & 0.042 & 0.0263 & 40.720 & 561.848 & -0.000021 & -2.039 & 0.103 & 0.00036 \\
\hline 3 & 62.122 & -0.059 & 0.0509 & 28.478 & 636.606 & -0.000031 & -02.073 & 0.207 & 0.00092 \\
\hline 4 & -1.195 & -0.045 & -0.0029 & 97.663 & 30.738 & 0.000456 & 0.348 & 0.219 & 0.00051 \\
\hline 5 & 8.664 & -0.039 & 0.1117 & 49.444 & -9.182 & 0.000165 & -0.113 & -0.057 & -0.00016 \\
\hline
\end{tabular}


Table (7) : Estimates of the variance of specific combining ability effect $\sigma^{2} \mathrm{si}^{\wedge} \mathrm{j}$ of the parents for studied characters.

\begin{tabular}{|c|c|c|c|c|c|c|c|c|c|}
\hline Parents & $\begin{array}{c}\text { Plant } \\
\text { height }\end{array}$ & $\begin{array}{c}\text { No. of } \\
\text { leaves/plant }\end{array}$ & LAI & $\begin{array}{c}\text { Leaves } \\
\text { Dry Wt. } \\
\mathrm{gm}\end{array}$ & $\begin{array}{c}\text { Total } \\
\text { biomass } \\
\mathrm{gm}\end{array}$ & $\begin{array}{c}\text { Leaf/stem } \\
\text { Photosynthe } \\
\text { tic rate } \\
\mu \mathrm{molm}^{2} \mathrm{~s}-1\end{array}$ & $\begin{array}{c}\text { Transpiratio } \\
\mathrm{n} \text { rate } \\
\mathrm{mmolm}^{2} \mathrm{~s}-1\end{array}$ \\
\hline 1 & 9067.0 & 5.586 & 2.089 & 2948.9 & 17869.9 & 0.044 & 16.052 & 0.395 & 0.00034 \\
\hline 2 & 2374.1 & 3.369 & 1.414 & 2841.3 & 12579.4 & 0.012 & 4.453 & 3.327 \\
\hline 3 & 3147.9 & 3.877 & 0.854 & 1604.3 & 15916.4 & 0.011 & 22.445 & -0.061 \\
\hline 4 & 5098.7 & 2.875 & 1.852 & 916.1 & 12828.4 & 0.020 & 57.303 & 1.768 & 0.00036 \\
\hline 5 & 4599.6 & 2.106 & 0.696 & 2312.9 & 5539.2 & 0.017 & 42.052 & 1.087 & 0.00219 \\
\hline
\end{tabular}

Table(8) : Estimates of some genetic parameters for studied characters

\begin{tabular}{|c|c|c|c|c|c|c|c|c|c|}
\hline $\begin{array}{c}\text { Genetic } \\
\text { parameters }\end{array}$ & $\begin{array}{c}\text { Plant } \\
\text { height } \mathrm{cm}\end{array}$ & $\begin{array}{c}\text { No. of } \\
\text { leaves/plan } \\
t\end{array}$ & LAI & $\begin{array}{c}\text { Leaves } \\
\text { dry } \\
\text { weight } \\
\text { gm/plan } \\
\text { t }\end{array}$ & $\begin{array}{c}\text { Total } \\
\text { biomass } \\
\text { gm/plant }\end{array}$ & $\begin{array}{c}\text { Leaf/ste } \\
\mathrm{m}\end{array}$ & $\begin{array}{l}\text { Photosyn } \\
\text { thetic } \\
\text { rate } \\
\mu \text { molm }^{2} \mathrm{~s} \\
\text { - }\end{array}$ & $\begin{array}{l}\text { Transpiratio } \\
\text { n rate } \\
\text { mmolm }^{2} \mathrm{~s}^{1}{ }^{1}\end{array}$ & $\begin{array}{c}\text { Stomatal } \\
\text { conductanc } \\
\mathrm{e} \\
\text { molm }^{2} \mathrm{~S}^{1}\end{array}$ \\
\hline Mse & 3.704 & 0.184 & $\begin{array}{c}0.02 \\
1\end{array}$ & 9.093 & 34.132 & 0.0002 & 6.047 & 0.194 & 0.0005 \\
\hline$\sigma^{2} \mathrm{GCA}$ & 195.364 & 0.063 & $\begin{array}{c}0.06 \\
3 \\
\end{array}$ & 59.484 & 314.743 & 0.0002 & 0.816 & 0.187 & 0.0006 \\
\hline$\sigma^{2} \mathrm{SCA}$ & 104.269 & 0.939 & $\begin{array}{c}0.37 \\
4\end{array}$ & 734.790 & $\begin{array}{c}5152.93 \\
9 \\
\end{array}$ & 0.0076 & 13.248 & 0.306 & 0.0008 \\
\hline $\begin{array}{c}\sigma^{2} \mathrm{GCA} / \sigma^{2} \mathrm{SC} \\
\mathrm{A}\end{array}$ & 1.874 & 0.024 & $\begin{array}{c}0.16 \\
8\end{array}$ & 0.081 & 0.061 & 0.0263 & 0.062 & 0.611 & 0.750 \\
\hline$\sigma^{2} \mathrm{~A}$ & 390.728 & 0.046 & $\begin{array}{c}0.12 \\
8 \\
\end{array}$ & 118.968 & 629.486 & 0.0004 & 1.632 & 0.374 & 0.0012 \\
\hline $\mathrm{a}^{-}$ & 0.731 & 6.389 & $\begin{array}{c}2.43 \\
6\end{array}$ & 3.515 & 4.046 & 6.164 & 4.029 & 1.279 & 1.155 \\
\hline
\end{tabular}




\begin{tabular}{|c|c|c|c|c|c|c|c|c|c|}
\hline $\mathrm{h}^{2} \mathrm{bs}$ & 0.993 & 0.843 & $\begin{array}{c}0.95 \\
9\end{array}$ & 0.989 & 0.994 & 0.976 & 0.711 & 0.778 & 0.800 \\
\hline $\mathrm{h}^{2} \mathrm{bs}$ & 0.783 & 0.039 & $\begin{array}{c}0.24 \\
2\end{array}$ & 0.138 & 0.108 & 0.049 & 0.087 & 0.428 & 0.480 \\
\hline
\end{tabular}


